\title{
AUTONOMIC NERVES MEDIATING CONTRACTILITY IN THE HUMAN GRAAFIAN FOLLICLE
}

\author{
GH. OWMAN, N.-O. SJÖBERG,* K.-G. SVENSSON AND B. WALLES $\dagger$ \\ Departments of Histology, *Obstetrics and Gynecology and $†$ Zoology, \\ University of Lund, S-223 62 Lund, Sweden
}

(Received 16th fune 1975)

Fluorescence histochemistry has shown that the human ovary is extensively supplied by adrenergic nerves, many of which are not associated with blood vessels and run in close contact with the follicles in a manner suggesting a local innervation (Owman, Rosengren \& Sjöberg, 1967). Particular attention has been paid to these adrenergic nerves since it became established by electron microscopy that the theca externa of the follicle contains smooth muscle cells (Okamura, Virutamasen, Wright \& Wallach, 1972). In order to elucidate whether the smooth musculature is involved in the contractility of the Graafian follicle, and whether neurogenic mechanisms can influence this function, a study was performed on material obtained from 32-48-year-old patients undergoing abdominal hysterectomy because of pains, bleeding, uterine myoma, or preinvasive carcinoma of the cervix. The follicles were dissected out, transported to the laboratory in ice-cold Krebs-Ringer solution (15 min), sectioned without previous fixation at $30 \mu \mathrm{m}$ in a Vibratome at $0^{\circ} \mathrm{C}$ and further processed according to the glyoxylic acid histofluorescence method for sensitive visualization of adrenergic nerves (Lindvall \& Björklund, 1974). Green-fluorescent adrenergic nerve terminals, running in an essentially meridional fashion, were found in the wall of the whole Graafian follicle (Pl. 1, Fig. 1) except for the most attenuated apex region. Away from the apex, the number of non-vascular nerve terminals increased and was highest in the intra-ovarian part of the follicle.

Adrenergic nerves were also demonstrated by electron microscopy in follicular material first incubated for $30 \mathrm{~min}$ in a Krebs-Ringer buffer solution containing $100 \mu \mathrm{g}$ of the false adrenergic transmitter, 5-hydroxydopamine $/ \mathrm{ml}$, and subsequently fixed in $3 \% \mathrm{KMnO}_{4}$ (Hökfelt, 1968). With this treatment the adrenergic terminals become selectively marked and are distinguished by the presence of numerous dense-cored vesicles, approximately $50 \mathrm{~nm}$ in diameter. Such terminals, often running in small bundles partly enclosed by a Schwann cell, were seen to approach smooth muscle cells to within about $100 \mathrm{~nm}$ (Pl. 2, Fig. 3). Occasionally, naked-axon varicosities were found only $20 \mathrm{~nm}$ from the membrane of a muscle cell (Pl. 2, Fig. 4), indicating the possibility for functional neuro-effector relations. A smaller number of nerve terminals was also found with exclusively agranular $50 \mathrm{~nm}$ vesicles, and these axons were also found in close apposition $(20 \mathrm{~nm})$ with smooth muscle cells (Pl. 2, Fig. 5). Such non-adrenergic nerves are probably identical with the acetylcholinesterasecontaining fibres that were seen by light microscopy (Pl. 1, Fig. 2) in tissues 
treated according to the histochemical techniques described by Holmstedt (1957) and Koelle (1963). These nerves had the same distribution in the follicle wall as the adrenergic ones but were less numerous.

It is evident, therefore, that the human follicular wall possesses structural prerequisites for a local mechanical activity and that autonomic nerves may play a role in this function. It has been reported that noradrenaline, adrenaline and acetylcholine exert a strong contractile action on isolated human follicular tissue (Walles et al., 1974). The types of amine receptors mediating the response have now been analysed in more detail using $2 \times 10 \mathrm{~mm}$ strips taken from the protruding part of the Graafian follicle and maintained in a covered organ bath containing an aerated Krebs-Ringer solution at $37^{\circ} \mathrm{C}$.
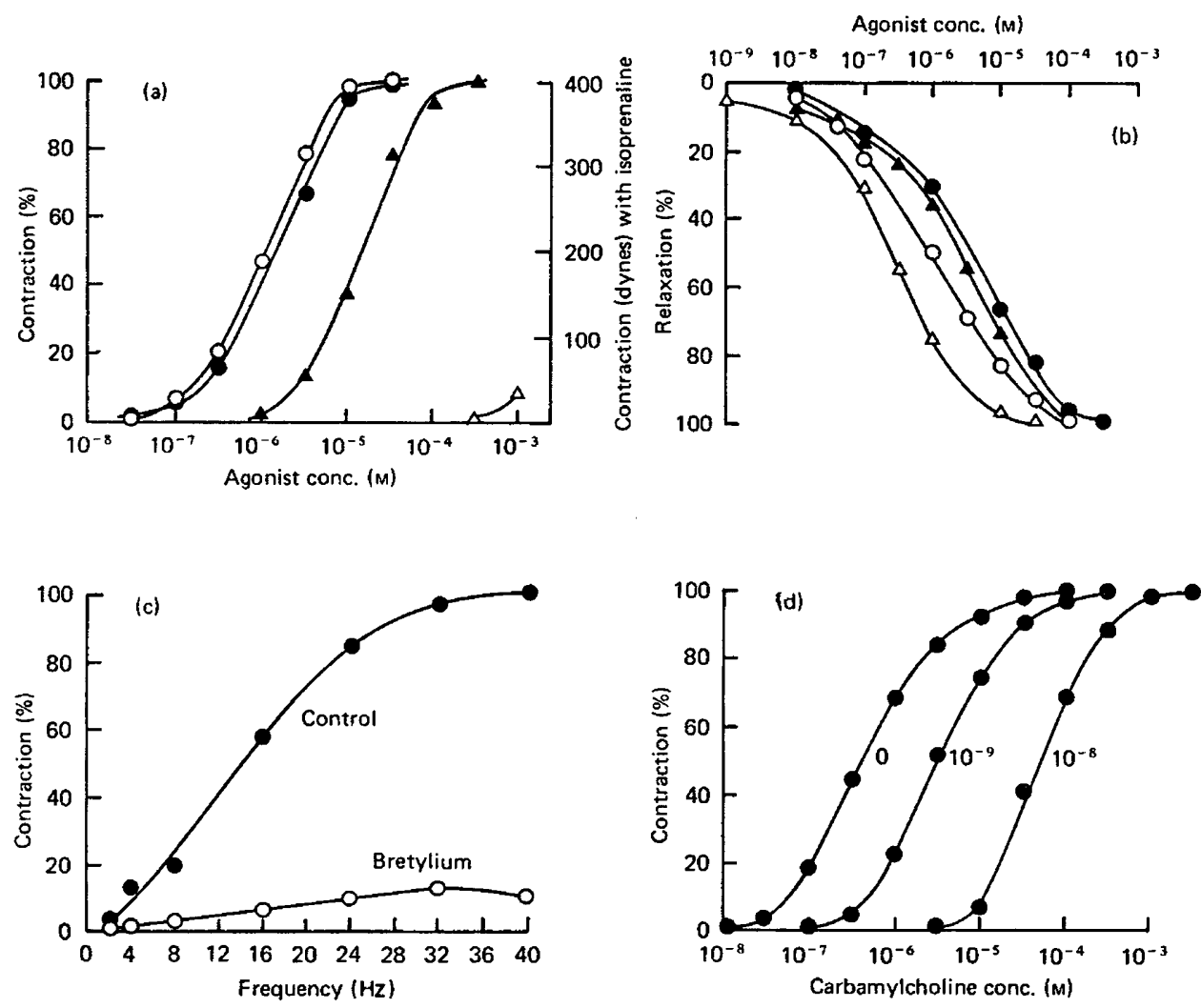

TExT-FIG. 1. Mechanical activity in vitro of strips from the protruding part of human follicles. Representative experiments in which $100 \%$ either shows the maximum response for each test $(a, b$ and $d)$ or the maximum response before blockade when this involves a reduction in the amount of response (c). Recordings were performed with a Grass FT03C force-displacement transducer and monitored on a Grass Model 7 polygraph. (a) Relative potencies for sympathomimetic compounds producing contraction of a resting strip in the presence of $10^{-6} \mathrm{M}$-propranolol (to block $\beta$-receptors) and $10^{-6} \mathrm{M}$ each of cocaine and normetanephrine (to block tissue uptake of amines). $O$, Noradrenaline; $\bullet$, adrenaline; $\Delta$, phenylephrine; $\Delta$, isoprenaline. (b) Relative potencies of sympathomimetic compounds producing relaxation of a strip, previously given an active tonic contraction by carbamylcholine, in the presence of cocaine and normetanephrine as above. In addition, the strip was pretreated for $30 \mathrm{~min}$ with dibenamine, which was then washed out, to block $\alpha$-receptors. Symbols as for (a) except for $\Delta$, terbutaline. (c) Contraction of strip by electrical field stimulation $(4 \mathrm{~V}, 1.0 \mathrm{msec})$ at increasing frequencies, and inhibition of the response by $10 \mu \mathrm{g}$ bretylium/ml showing that the effect is mediated by adrenergic nerves. (d) Contraction of follicle strip by carbamylcholine before and after addition of increasing doses of atropine, illustrating the competitive reversible nature of the antagonism. 
PI.ATE 1
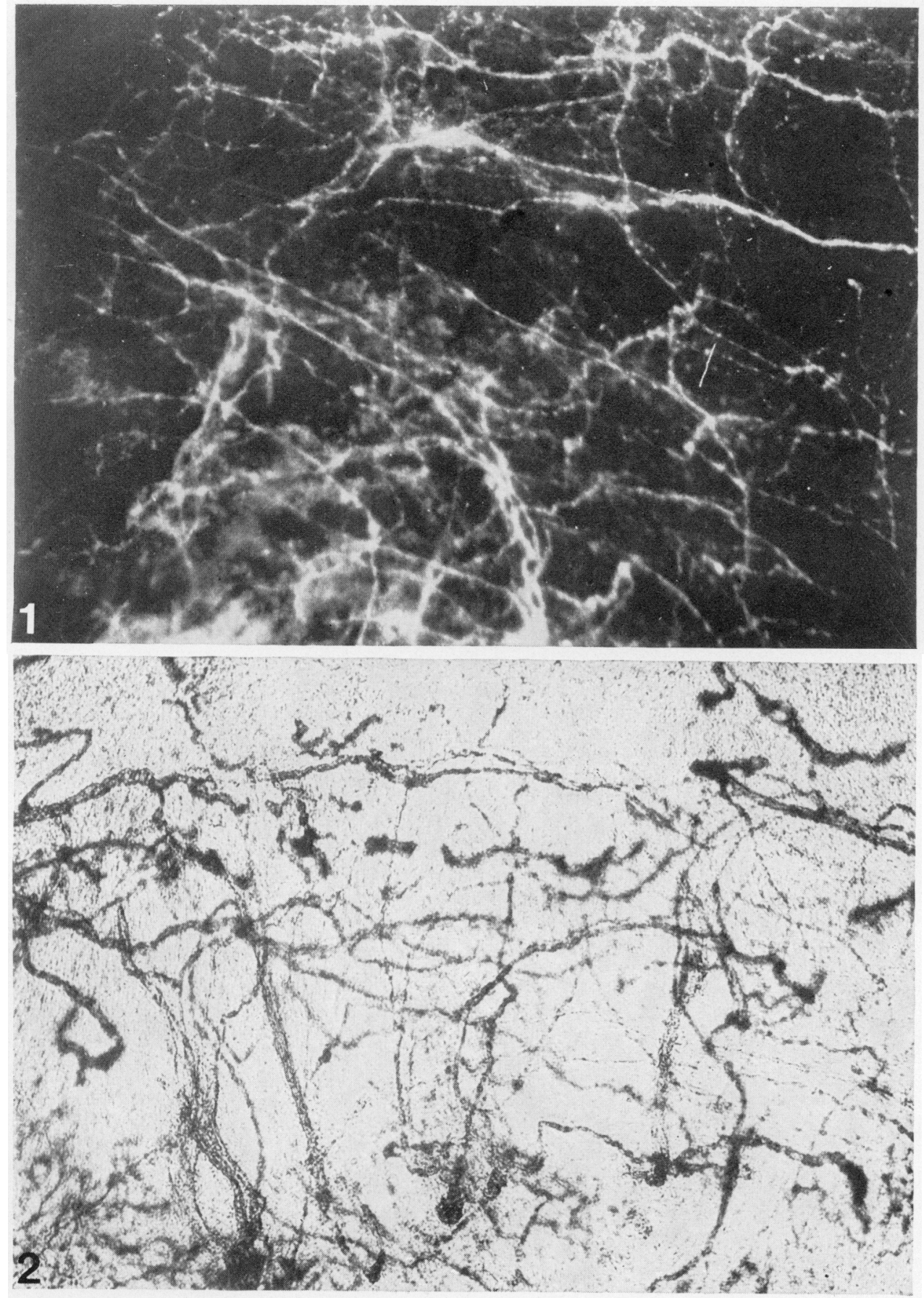

FIG. 1. Fluorescence micrograph showing numerous noradrenaline-containing fibres in the theca externa of a meridional section of the wall of a human follicle. $\times 210$.

FIG. 2. I.ight micrograph from the same part of the follicle demonstrating cholinergic nerves by the cholinesterase method: preincubation with $4 \times 10^{-6} \mathrm{~m}$ of the pseudocholincsterase inhibitor, Mipafox (N,N'-di-iso-propyl-phosphorodiamide fluoride), followed by incubation for $8 \mathrm{hr}$ in the presence of acetylthiocholine iodide. $\times 150$.

(Facing $p .5 .54$ ) 
PLATE 2

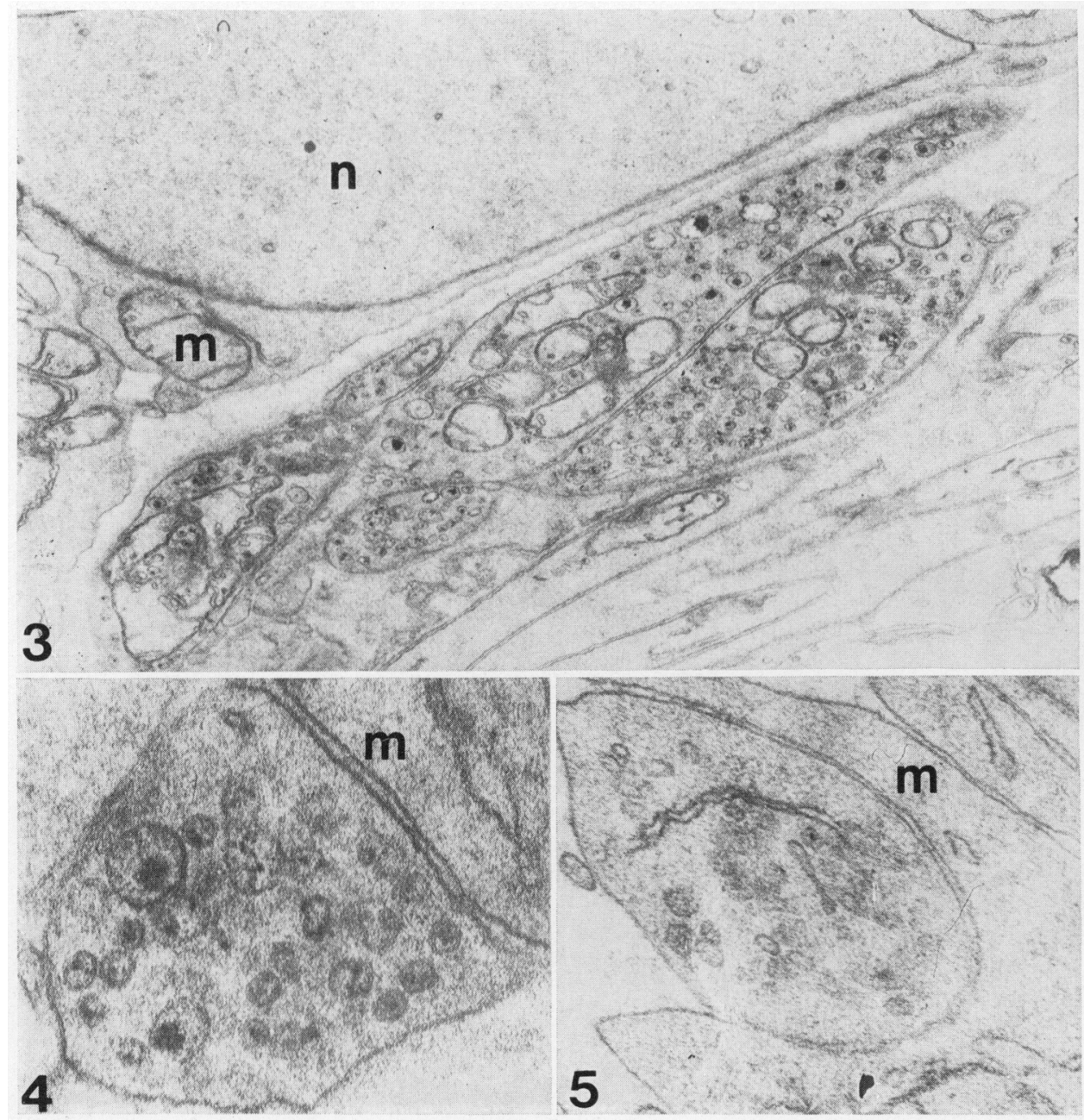

Fig. 3. Electronmicrograph from human follicle wall, incubated with 5-hydroxydopamine and fixed in $\mathrm{KMnO}_{4}$, showing a bundle of adrenergic axons (characterized by numerous electron-dense vesicles), partly enclosed by a Schwann cell, approaching a smooth muscle cell $(\mathrm{m})$ containing mitochondria; $\mathrm{n}=$ nucleus. The distance between the membrane of the muscle cell and the adjacent axon varicosity is $100 \mathrm{~nm} . \times 19,000$.

FIG. 4. Naked adrenergic axon varicosity $20 \mathrm{~nm}$ from membrane of a smooth muscle cell $(\mathrm{m}) . \times 69,000$.

FIG. 5. Non-adrenergic, probably cholinergic, axon varicosity (containing agranular vesicles) invaginated into a smooth muscle cell $(\mathrm{m}) . \times 49,000$. 
Full cumulative dose-response curves (see van Rossum \& van den Brink, 1963) showed that the compounds mediating the contractions (sometimes amounting to 700 dynes) had a potency rank (comparison if $\mathrm{ED}_{50}$ values) of noradrenaline $>>$ adrenaline $>$ phenylephrine $>$ isoprenaline (Text-fig. 1a). The effect was inhibited in a characteristic manner by the irreversible $\alpha$ receptor antagonist, phenoxybenzamine. Calculation of the dissociation constant for the receptor-agonist complex $\left(\mathrm{K}_{\mathrm{A}}\right)$ gave a value of $(1.68 \pm 0.44) \times$ $10^{-6}$ м (mean \pm S.E.M.; five experiments) which conforms to a typical $\alpha$ receptor (Furchgott, 1972).

Relaxation responses were studied under conditions when the $\alpha$-receptors were blocked by dibenamine $\left(3 \times 10^{-6} \mathrm{M}\right)$ and after the preparation had been given an active tonic contraction of 200-300 dynes by carbamylcholine $\left(1 \times 10^{-6}\right.$ $\left.3 \times 10^{-6} \mathrm{M}\right)$. The order of potency for the induction of relaxation by the test compound was isoprenaline $>$ noradrenaline $>$ terbutaline $>$ adrenaline (Text-fig. 1b), and indicated that relaxation of the human follicular wall is mediated by $\beta$-receptors (Persson \& Olsson, 1970).

Contraction in the follicular wall involving $\alpha$-receptors and release of noradrenaline from the local adrenergic nerves was shown by electrical field stimulation. When trains of stimulation (pulse duration $0.6-1.0 \mathrm{msec}$ ) lasting $5 \mathrm{sec}$ were used, the follicle strip started to contact after a short latency, reached maximum soon after the end of stimulation, and then rapidly relaxed. By repeating this stimulation procedure at increasing pulse frequencies it was shown that the amount of contraction was frequency-dependent (Text-fig. 1c). The response was inhibited by $10^{-6} \mathrm{M}$-piperoxan, an $\alpha$-receptor antagonist, and almost completely abolished by $10 \mu \mathrm{g}$ bretylium $/ \mathrm{ml}$ (Text-fig. lc), an inhibitor of noradrenaline release.

Acetylcholine and carbamylcholine always induced contraction in the preparations. Administration of atropine in increasing concentrations into the organ bath $20 \mathrm{~min}$ before cumulative administration of acetylcholine or carbamylcholine caused a shift of the dose-response curve towards higher concentration of the agonist (Text-fig. 1d). In the experiments performed for determination of the dissociation constant of the receptor-antagonist complex $\left(\mathrm{K}_{\mathrm{B}}\right)$, carbamylcholine was used in order to avoid interference with acetylcholinesterase present in the tissue. That the response involved a simple bimolecular reaction according to receptor theory (Furchgott, 1972) was confirmed in the Arunlakshana-Schild (1959) plot which showed a good linearity $(r=0.99)$ and a slope of $-1 \cdot 14$ (not significantly different from unity, $P>0.05$ ). The $\mathrm{K}_{\mathrm{B}}$ value for the receptor-atropine complex was thus found to be $(1 \cdot 17 \pm 0 \cdot 13) \times$ $10^{-10} \mathrm{M}$. The presence of muscarinic receptors together with the close relationship of non-adrenergic (presumably cholinergic) nerves with follicular smooth muscle cells indicate that a contraction of the follicle wall can be elicited not only by the sympathetic but also by the parasympathetic system.

To determine whether the induced mechanical activity in the human follicular strips reflects changes in intrafollicular pressure, a $0.5-\mathrm{mm}$ wide cannula was introduced through the ovarian tissue into the follicular antrum. The ovarian preparation was immersed in the aerated organ bath described above and pressure recordings were performed with a Statham P23AG transducer. The basal pressure was $120-150 \mathrm{~mm} \mathrm{H}_{2} \mathrm{O}$. A dose-dependent increase in 


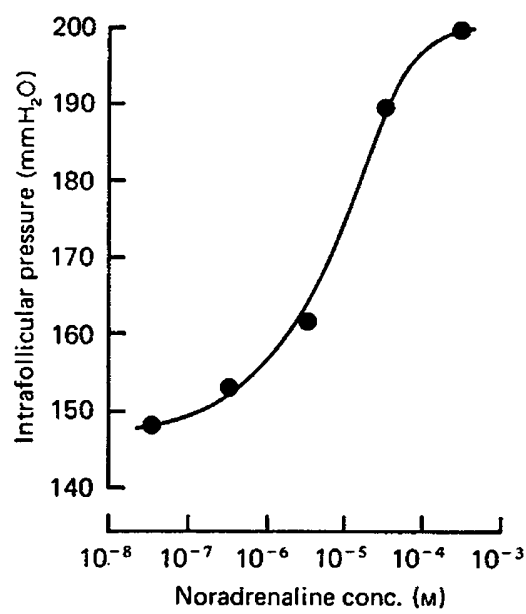

TExT-FIG. 2. Intact human follicle with surrounding ovarian tissue immersed into an organ bath containing aerated Krebs-Ringer buffer solution at $37^{\circ} \mathrm{C}$. Typical experiment showing elevation of intrafollicular pressure after administration of increasing concentrations of noradrenaline into the bath.

intrafollicular pressure (Text-fig. 2) was found after addition of noradrenaline to the organ bath (three experiments).

The study shows that, in the human ovary, the autonomic nervous system can affect the mechanical activity of the follicular wall and intrafollicular pressure and suggests the possibility of a neurogenic influence on the gonadotrophin-controlled follicular development and ovulation process.

The work was supported by grants from the Ford Foundation and the World Health Organization.

\section{REFERENCES}

Arunlakshana, O. \& SCHILd, H.O. (1959) Some quantitative uses of drug antagonists. Br. F. Pharmac. Chemother. 14, 48-58.

FuRGHGOTT, R.F. (1972) The classification of adrenoceptors (adrenergic receptors). An evaluation from the standpoint of receptor theory. In Handbook of Experimental Pharmacology, Vol. 33, pp. 283-335. Eds H. Blaschko \& E. Muscholl. Springer, Berlin.

Holmstedt, B. (1957) A modification of the thiocholine method for the determination of cholinesterase. II. Histochemical application. Acta physiol. scand. 40, 331-357.

Koelle, G.B. (1963) Cytological distribution and physiological functions of cholinesterases. In Handbuch der experimentellen Pharmacologie, Suppl. 15. Ed. G. B. Koelle. Springer, Berlin.

Lindvall, O. \& BJöRKLund, A. (1974) The glyoxylic acid fluorescence histochemical method: a detailed account of the methodology for the visualization of central catecholamine neurons. Histochemistry 39, 97-127.

Okamura, H., Virutamasen, P., Wright, K.H. \& Wallach, E.E. (1972) Ovarian smooth muscle in the human being, rabbit, and cat. Histochemical and electron microscopic study. Am. F. Obstet. Gynec. 112, 183-191.

Owman, Ch., Rosengren, E. \& Sjöberg, N.-O. (1967) Adrenergic innervation of the human female reproductive organs: a histochemical and chemical investigation. Obstet. Gynec., N. Y. . 30, 763-773.

Persson, H. \& Olsson, T. (1970) Some pharmacological properties of terbutaline (INN), 1-(3,5dihydroxyphenyl)-2-(T-butyamino)-ethanol. A new sympathomimetic $\beta$-receptor-stimulating agent. Acta med. scand., Suppl. 512, 11-19.

van Rossum, J.M. \& van DEN BRINK, F.G. (1963) Gumulative dose-response curves. 1. Introduction to the technique. Archs int. Pharmacodyn. Ther. 143, 240-246.

Walles, B., Edvinsson, L., Falck, B., Nybell, G., Owman, Ch., SJöberg, N.-O. \& Svensson, K.-G. (1974) Modifications of ovarian and follicular contractility by amines. A mechanism involved in ovulation? Eur. F. Obstet. Gynec. Reprod. Biol. 4, Suppl., S103-S107. 